\title{
ASSOCIATION OF AMAZONIAN UNIVERSITIES (UNAMAZ) \\ ASSOCIAÇÃO DE UNIVERSIDADES AMAZÔNICAS ASOCIACIÓN DE UNIVERSIDADES AMAZONICAS
}

\author{
Campus Universitário \\ Guamá \\ 66050 Belém \\ Pará (Brazil) 1987 \\ Fax: (91) 229-4339 \\ Telex: 910881 mnra br \\ President: Dr. José Seixas Lourenço \\ Executive Secretary: Maria de Nazaré \\ Oliveira Imbiriba
}

A civil, non-profit making society which englobes Research and Educational Institutions of the Amazonian countries: Bolivia, Brazil, Colombia, Ecuador, Guyana, Peru, Suriname, and Venezuela. Its main task is to foster international cooperation among the Amazonian universities in projects in the scientific, technological and cultural field to the benefit of the social and economic development of the people from the Amazon, and the preservation of the regional environment.

L'Association des universités amazoniennes (UNAMAZ) est un organisme public, à but non lucratif, qui regroupe les institutions de recherche et d'éducation des pays de l'Amazonie: Bolivie, Brésil, Colombie, Equateur, Guyana, Pérou, Suriname et Venezuela. Sa tâche principale consiste à encourager la coopération internationale parmi les universités amazoniennes en les intéressant aux projets des domaines scientifique, technologique et culturel au bénéfice du développement social et économique de la population de l'Amazonie et de la préservation de l' environnement régional. 